\title{
COMPARATIVE LAW AND THE PROCESS OF DE- JURIDIFICATION: THE JOINT-EMPLOYMENT LAW CASE IN LABOUR LAW
}

\author{
Andrea Sitzia ${ }^{*} \&$ Filippo Viglione $e^{* *}$
}

\begin{abstract}
The process of de-juridification is, in some respects, ambiguous and paradoxical. While in certain areas, we see a proliferation of detailed legislative regulations, in others, we detect tendencies pointing in the opposite direction. One of the most interesting cases is that of labor law, where both tendencies emerge. Recent reforms in many European countries show a trend towards a relaxation of rules, inspired by the aim to stimulate growth in employment. In this context, the newly-introduced concept of "joint employment" plays a pivotal role. The process of de-juridification clearly invests labor law, in particular within enterprise networks, where arrangements under joint employment seem to give the parties of a commercial contract the highest standard of contractual freedom. This social phenomenon is not therefore regulated by detailed legislative provisions, but simply through non-specific norms inspired by general goals. In considering several recent reforms of labor law in European countries, in this paper, we aim to determine the real level of dejuridification currently present within traditionally rigid legislative systems.
\end{abstract}

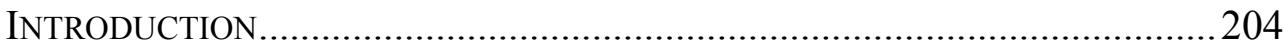

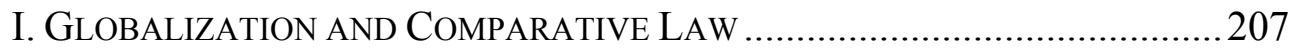

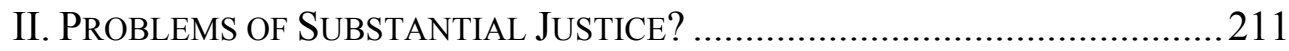

III. ECONOMY, RigHTS AND INSTITUTIONS: A COMPARATIVE APPROACH .. 214

IV. DisARTICULATION AND INTEGRATION OF ENTERPRISE STRUCTURES. THE

CASE OF CO-EMPLOYMENT .............................................................. 217

V. The ItAlian CASE: Enterprise Network Labor SituAted BETWEeN

DE-REGULATION AND NEO-REGULATION .............................................. 221

VI. THE ENTERPRISE NETWORK CONTRACT. RELATIVE NORMS AND

IMPORTANT GUIDELINES PERTINENT TO LABOR LAW ..............................2224

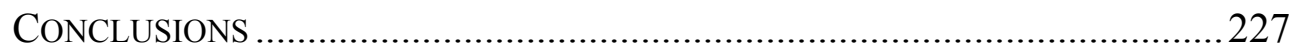

\section{INTRODUCTION}

The process of de-juridification is, in some respects, ambiguous and

\footnotetext{
${ }^{*}$ Andrea Sitzia is Assistant Professor of EU Labor Law at the Department of Political and Juridical Sciences and International Studies in the University of Padova-Italy.

${ }^{* *}$ Filippo Viglione is Associate Professor of Comparative Private Law at the same Department. This paper is the joint work of the two Authors. A. Sitzia personally wrote paragraphs IV, V and VI; F. Viglione wrote paragraph I-III.
} 
paradoxical. Focusing on labor law, in this paper, we shall attempt to determine whether one can detect an evolutionary pathway of juridical ordinances capable of revealing the level now reached by the dejuridification stage. We shall start out by defining "de-juridification" rather simply, as the phenomenon by which juridical relations, in the past strictly confined to the sphere of norms set out by national States, are nowadays often left to private regulation processes.

In order to understand the scope of this trend, we must recognize both the internal and the external nature through which it operates.

On one hand, then, within the internal sphere, and particularly in the field of private law relations, we see private autonomy taking over vast swathes of terrain. Undeniably, private relations have always formed the kingdom of autonomy and liberty; but never, before today, had State authorities granted private actors such wide freedom of movement among regulating instruments and governance mechanisms affecting these relations.

This occurs most strongly in the area of family law, in which dejuridification has long been commonly accepted; family law is more and more frequently entrusted to negotiation instruments, in the face of which the State's task is limited to monitoring and surveillance (consider the unopposed diffusion of prenuptial contracts, of cohabitation agreements, and stipulations of responsibility within the family).

However, it is not only the area of family law which knows a sort of "mandate" given to the private actor, to deal with private relations. To mention what may be the best-known instances of de-juridification, only consider the lex mercatoria: a manifestation of the State's actual retreat in favor of regulatory instruments throughout the world, though remaining in the hands of private, autonomous actors. ${ }^{1}$ In this perspective, the contract becomes the primary source of regulation for international commercial relations.

We need only recall, here, that Western juridical doctrine has widely acknowledged the emersion of "soft" norms regulating relations between private actors. "Soft law", once a simple object of interest for juridical sociologists, has now become pivotal both to general juridical theory and to the study of positive law.

Seen in this double perspective, internal and external, the relationship

\footnotetext{
${ }^{1}$ For discussion in the context of legal pluralism, see B. Z. Tamanaha, Understanding Legal Pluralism: Past to Present, Local to Global, 30 Sydney Law Rev. 375-411 (2008). On page 376, he speaks of "an evident increase in quasi-legal activities, from private policing and judging, to privately run prisons, to the ongoing creation of the new lex mercatoria, a body of transnational commercial law that is almost entirely the product of private law-making activities".
} 
linking the phenomenon of globalization to the world of law reveals new horizons every day. Sometimes the horizons reflect the need to grasp positive aspects of juridical mundialization (recall the planet-wide diffusion of human rights); other times, they mark areas of darkness varying in kind. Despite the complexity and instability in which we live today, we seem to have reached some degree of consensus concerning the weakness of the traditional vision of sovereignty: a vision subject to concentric attacks proceeding, on the lower level, from local normative production and from spaces relegated to private autonomy; and on the higher level, from international organizations endowed with growing power, both political and non-political. Other numerous factors join in chipping away at sovereignty in crisis.

Any observer of reality can clearly see that in time, the progressive abandonment of the idea of sovereignty, as traditionally understood, may well destroy the concept of State "borders" which has formed the building blocks of today's national States. ${ }^{2}$ This does not mean that, the juridical conditioning produced by the globalization process is limited to international law, to the issue of "external" sovereignty; for inevitably, it will also involve internal sovereignty. Monolithic as it was in the past, internal sovereignty will be challenged by new forms of power which have received some legitimation by defining legal rules, even ones of a private character; or in any case, by influencing the decisions based on them.

The resulting conundrum is tied, first of all, to the sources of law: in particular, to the acknowledged weakening of national law, which is retreating on a horizontal plane as terrain is gained by the financial economy, by the regulatory function of the contract, by the predominance of international juridical bodies: all signaling an inversion of direction with respect to the juridification process experienced by Western societies in the recent past.

With this spontaneous process, which conceals the transfer of State functions to the market or to supranational organizations, the very idea of "border" is thus emptied of meaning, torn down by the advent of a "borderless law" emblematically represented by Internet. It is no mere coincidence that, attention toward human rights has found a possibility for full theoretical development in the framework of globalized law; almost as if the overcoming of local particularisms could create the chance to universally protect human rights, even while running the risk of excessively affecting traditional processes guiding the production of juridical rules. As

\footnotetext{
${ }^{2}$ J. Habermas, The Postnational Constellation (MIT Press 2001).
} 
we know, such processes are slow to break away from the differences in history, culture, religious roots and levels of social development within different countries.

If we examine so-called "stateless law", we clearly see that, the necessary requirement for any progressive unification of the rules effectively observed in regulating relations between private actors, is the growing homogeneity of social and economic conditions. Instead, the globalization process seems to follow a completely different logic, in which movements are hetero-determined according to the pressures exercised by variously identified centers of trans-national power, ${ }^{3}$ or through an Americanization of the law. ${ }^{4}$ Such conditions challenge juridical scholars in a way different from the past, especially as regards comparative law; we must adjust our focus on the object of juridical analysis. The examined juridical phenomenon is clearly destined to expand, to redefine interrelational spaces through "soft law", and to clarify new forms of social rule not bound by the traditional centers of State power.

As many observers point out, indeed, with the suppression of territorial limits on manufacturing processes and product distribution, the transformations in international economy and finance result in legal changes as well; new types of "frontier" are emerging on a world-wide scale, which we might call "non-material", dynamic. They present a new common denominator, independent of the territorial element. Undeniably, however, recent events linked to the crisis festering from 2008 on have unmasked the glibness of those who predicted the rapid death of State structures and national sovereignties.

It soon becomes clear, then, that, our analysis of reality will have to confront complexity. We shall consider not only traditional divergences among rules according to the different national States or legal families encompassing them, but also the new dynamics which have partly modified, if not terminated, the evolutionary pathway of modern States.

\section{GLOBALIZATION AND COMPARATIVE LAW}

As we study the processes which are redefining sources of law on a global scale, it will be useful to consider case studies revealing that, State's normative capacity is in retreat. However, such analyses must be supported by adequate methodological instruments allowing us to verify whether such

\footnotetext{
${ }^{3}$ M. Siems, Convergence in Shareholder Law (Cambridge University Press 2008), passim.

${ }^{4}$ On the possible Americanization of law, see the plurality of viewpoints expressed in the essays,

L'américanisation du Droit, 45 ARChIVES DE PhILOSOPHIE DU DroIT (Dalloz 2001).
} 
events can be framed within a coherent context of de-juridification, or are, instead, extemporaneous manifestations of normal dialogue between sources of law.

In this perspective, comparative law, which has always posed a challenge to legal positivism, may prove highly useful in order to detect unifying traits among different national legal systems, and to reveal any contrast standing between formal declarations and actual operative rules.

Therefore, before examining here the labor-law case study represented by co-employment, we shall sketch out the general context enveloping the phenomenon of legislators' backwardness as regards labor law. More generally, we shall methodologically analyze the present state in which comparative studies abide.

Traditional social science research methods may clearly apply both to global transformations and to studies in comparative law. The phenomenon of globalization will influence legal thought in a variety of ways. We need only recall the opportunity to resolve in a global manner several problems emerging in today's society: the solutions must be found in shared choices, as is the case for environmental problems, issues touching on the protection of intellectual property, and the phenomenon of international money laundering.

The challenges posed by globalization to legal structures also concern actors whose dealings are not confined within national State borders; in fact, they include various non-governmental organizations and international law firms which help create a homogeneous language and common rules.

A marked de-territorialization of borders thus clearly emerges: suffice it to consider the guiding role played by multinational private actors, both in setting out contract models and in settling disputes on an international level. We see, then, how de-territorialization also reveals an aspect of dejuridification: e.g., the diffusion of standard contract models involves both an absence of ties to national legal disciplines and, more generally, an ascription of regulatory power to private actors. ${ }^{5}$

Therefore, comparative law is now called upon to redefine its role, in light of the transformations affecting today's juridical systems: transformations marked by a new vagueness of borders. From a certain viewpoint, then, the establishment of a global legal order may well cause disorientation in the face of the growing complexity of the phenomenon we are observing, according to several disconcerting opinions which throw

\footnotetext{
${ }^{5}$ Recall the well-known idea that, the rise of spontaneous law-making will necessarily weaken the traditional hierarchy of internal sources. See G. Teubner, "Global Bukowina": Legal Pluralism in the World Society, 3 Global Law Without a State (Dartmouth 1997).
} 
doubt on the very survival of any real possibility for comparison. ${ }^{6}$

In any case, such worries seem destined to disappear, if one reflects on a paradoxical demand: i.e., in the globalized context itself, every jurist considers national realities which are no longer completely autonomous, in which juridical pluralism and the multiple levels of regulatory power require reasoning based on knowledge and on an adequate capacity for comparison. As noted above, in a sense, every jurist today must be a true comparativist. ${ }^{7}$

It often seems indeed that, paradoxically, the phenomenon of dejuridification may generate numerous wide-spread centers of normative power, whose products today represent a new testing laboratory for tools pertinent to legal studies.

Significantly, the well-known United States Supreme Court decision in Lawrence vs Texas, ${ }^{8}$ caused widespread attention for having admitted recourse to the decisions of foreign constitutional courts in order to interpret constitutional norms. The very use of comparison in jurisprudence finds support today in important currents of thought, which consider it to be an effective interpretative tool, an instrument capable of shedding empirical light on the possible consequences engendered by the existence of differing solutions to the same legal problem. ${ }^{9}$ Such characteristics of comparison appear all the more vigorous in the presence of a multi-level legal reality, in which interrelations among legal structures reveal reciprocal influences. We must acknowledge them and attempt to understand them fully.

Above and beyond any meaning or value judgment we may actually apply to the phenomenon of globalization, in fact, we are undeniably confronting a model of global "governance" $" 10$ constructed on various levels. Each level presents different instruments for regulating society, as well as various techniques for interpreting or describing reality. Different instruments will be variously compatible with differing legal models.

These various governance levels correspond to various types of "border", arising in relation to the territorial functions carried out according to various governmental demands; just consider, e.g., the profound meaning

\footnotetext{
${ }^{6}$ M. Siems, The End of Comparative Law, 2 J. Comp. L. 133-150 (2007).

${ }^{7}$ W. Twining, GLOBALIZATION AND LEgal THEORY 255 (Butterworth 2000).

${ }^{8}$ Lawrence v. Texas, 539 U.S. 558 (2003).

${ }^{9}$ Printz v. United States, 521 US 898 (1997), 2377 (Breyer J). Of course, the jurisprudential use of comparison has long been central to a seminal discussion, an arousing particular attention in comparativistic doctrine; see the recent G. CANivet, M. ANDENAS, \& R. FAIRgrieve, Comparative LAW BEFORE THE COURTS (G. Canivet, M. Andenas, \& R. Fairgrieve, eds., British Institute of International and Comparative Law 2004).

${ }^{10}$ We use the term "governance" here in the sense proposed by the World Bank, as the supervision of economic and administrative resources. "Governance" is generally contrasted to "government", indicating the political governing of single nations.
} 
ascribed to the territorial frontier of the European Union, which is quite different from that attributed to the simple sum total of the member States' national borders. ${ }^{11}$

The result of actions shared by such concurrent factors makes globalization difficult to decipher. Many ambiguities and enigmas mark it. ${ }^{12}$

However, in the immeasurable doctrinal panorama on such themes, one can detect discourse tending to favor a new world legal order. This new global order would be based on the conviction that every juridical system shall be able to travel along analogous evolutionary pathways marked by respect for the rule of law; at the same time, it would define as a priority, in the governance acts of international organizations, the furthering of a colonization process which, through the persuasion of economic force, shall define new processes of reform.

Behind the veil of a supposed spontaneity in the birth of a new lex mercatoria, we thus seem to detect the realization of a true and proper program involving various institutional structures. Such structures would not only tend to legitimize a legal system predominating over national laws, but also to further the development of local juridical rules guided by criteria extraneous to the systems called upon to apply them by way of various international development agencies. Certain observers, then, struck by doctrinal texts concerning the principles of international commercial contracts, ${ }^{13}$ gain only a fragmented vision of the phenomenon: They believe that, the political mediation of the interests at play (a constant trait of the legislative rule created by States) is substituted today by the cultural mediation of jurists. What threatens, then, is a harmful disruption in the linearity of traditional comparative law discourse. Our discourse, instead, must be constantly aware of new variables, of their influence, and of the possible crises of rejection which may ensue.

\footnotetext{
${ }^{11}$ In this perspective, we may detect a possible line of development in the very idea of "border". Redefined on levels which may be different from territorial ones, the concept may, in any case, satisfy the need to render democratic processes effective, or contribute toward the protection of each person's rights and opportunities (M. SLAUGHTER, A NEW World ORder (Princeton University Press 2004), passim). This explains why, for example, the European Court of Human Rights, even while wielding the tool of human rights - universal and absolute by nature - makes wide use of comparative law, which instead, validates specific local peculiarities.

${ }^{12}$ See Basil Markesinis' criticism of the way in which comparative doctrine deals with the theme of globalization, mixing up in a single melting pot law, economics, politics and history, so that the high aspirations of analysis cannot result in useful practical measures (B. MARKESINIS, \& J. FEDTKE, ENGAGING WITH FOREIGN LAW 365 (Hart Publishing 2009).

${ }^{13}$ The opinion contested, which validates the doctrinal contribution while partly canceling out the political aspect, is actually widespread in the international literature. See, among others, J. P. Robé, Multinational Enterprises: The Constitution of a Pluralistic Legal Order, GLOBAL LAW WITHOUT A STATE, 45-78 (G. Teubner, ed., Dartmouth 1997).
} 


\section{Problems of Substantial Justice?}

In examining the dynamics of de-juridification, we immediately detect a possible problem regarding substantial justice. As time passed, in admittedly divergent ways, State normative structures have refined instruments for social justice, often in an attempt to correct the imbalance in private relations where strong and weak parties defended their respective interests. In the area of labor law, a State's juridical system will thus tend to offer a framework set up to protect the weaker individuals.

As the State retreats in its role of disciplining private relations, the need arises to determine whether or not guarantees and protection for the weaker parties (e.g., consumers, workers, renters) still find adequate space, even though the rules are now dictated within a context of de-jurification exalting the autonomy of private individuals.

Similarly, the problem corresponds to the progressive weakening of the State monopoly over normative production. Until now, this monopoly had constituted a founding trait of the geopolitical system, in which State territory and judicial space were meant to coincide. In this context, the legal dimension might be defined in relation to a physical space delineated by the national borderline, inside of which all the main actors stood in a relationship nearly exclusive to national sovereignty. This model of juridical organization was space-bound, as well, in its belonging to a community, so that it was easy to picture juridical rules as a univocal expression of the "people" residing within given geographical borders.

Instead, as we well know, today's global dynamics suggest a progressive abandonment of the territorial exclusiveness of law. For example, not only do products and services become exportable objects, but institutions and legal rules as well. In some respects, the membership delineated by national boundaries loses much of its meaning, since the circulation of products and people breaks the very unity of national interests, creating a new sense of belonging, linked not to space but to the particular status of individual persons (such as the European "consumer").

Arguably, then, the State's retreat in its role of regulating private legal relations, represents the other side of the coin in the process of relinquishing external sovereignty in favor of supra-national organizations or the selfregulating force of the market. The jurist must confront both of these directions, which together mirror a geopolitical reality still in flux. Interestingly, the process of de-territorialization is capable of arousing differing reactions according to the various contexts under observation. The very analysis of globalization's impact on the network of traditional 
situations becomes crucial to understanding current law.

It is not surprising, then, that, possible reactions include the attempt to block the permeability of borders. This attempt glimmers through the discursive mesh of persons educated in the positivist, tradition of law who criticize the new dynamics of globalized law. It may also manifest itself in discussions concerning the "democracy deficit" of supra-national organizations. $^{14}$

There are actually many ways in which one may attempt to set up a barrier restoring value to territorial sovereignty. Several of those ways are highly dangerous, particularly when a model of competition emerges favoring the excessive leveling of juridical rules, limited space-wise but precipitating, substance-wise, in downward homologation. We see an emblematic example of this in the diffuse compression of workers' rights meant - say some - to endow enterprises with greater competitiveness on the global market.

In this perspective, legal competition becomes an instrument capable of transmitting uniform rules, suggested by the persuasive force of economic interests and sustained by the doctrinal legitimation of a labor-law "best model", and by mathematic indicators of efficiency. In numerous cases, we see a downward homologation of norms, as witnessed by comparative studies. Cases pertaining to labor law stand out emblematically.

In other instances, the reaction to border crises emerges in an even more conservative direction, especially if new territorial borders are being proposed to encompass populations which are smaller in number but more homogeneous. In any case, the latter phenomenon transmits a contradictory message as regards the very existence of borders, for on one hand, the advent of new borders sends out a clear sign of affection towards the traditional border concept; while from the viewpoint of the international community, it contradicts the sovereign delimitation of spatial relations as regulated by international law concerning State borders.

When this occurs, it is difficult to predict where the rules regulating private life will end up. One pathway may lead, however indirectly, to the neglect of local legal culture, traditions and mentality in favor of importing rules from a different tradition. Fundamentally, though, the erection of new territorial borders reveals one of the inconsistent aspects of globalization which, on one hand, weakens the very idea of State sovereignty, but on the other, fails to replace it with a true sense of global community.

Such processes, consolidated at the beginning of the third millennium,

\footnotetext{
${ }^{14}$ C. Aman, The Democracy Deficit: Taming Globalization through Law Reform, 81 (NYUP 2004).
} 
pose new questions to anyone attempting to use the instruments of comparison in order to analyze the reality. We must be aware of the progressive weakening of national State powers, which, on the higher level, is revealed by the normative predominance of supra-national organisms, and on the lower level, results in a delegation of powers to private autonomy. Such awareness should help us understand why traditional borders are losing meaning and epistemological value, even while different kinds of borders simultaneously arise; borders that are ever more important in the lives of each person, though they are devoid of traditional physicality.

These new frontiers re-propose the twofold nature, both inclusive and exclusive, characterizing any border, gathering together individuals around common denominators and erecting walls in order to protect them against outsiders.

"Complexity" remains the key to deciphering the new dynamics presented by globalization. A mixture of factors drives the process: fundamental human rights, the protection of minorities, environmental protection, sometimes by way of national borders' "porosity". As the process continues, new-generation rights are joined by the homologation of rules as dictated by multi-national economic power. In this perspective, it seems that the universality of fundamental human rights itself is used as a personal weapon of self-legitimation, obliterating discourse concerning social rights. Significantly, it is within the sphere of the World Bank and the World Trade Organization that, in recent years, we have seen the strongest push towards the recognition or imposition of human rights, owing to the clear strategy for including "humanitarian" factors which, during the last ten years, has characterized the life of the principle world governance organizations. ${ }^{15}$

A reflection regarding the object of comparative analyses will therefore allow us to rid the field of a possible misunderstanding, which might arise from an emotional reading of the globalization process. The decline of national borders, devoid of their traditional impermeability, does not weaken the heuristic relevance of laws in national States, provided that, even today, we can find an essential trait of comparison through their reciprocal confrontation and through the search for similarities and distinctions.

\footnotetext{
${ }^{15}$ The literature dedicates a great deal of attention to the emerging connection between human rights discussion and activities of the World Trade Organization. See, among others, J. Harrison, The Human Rights Impact of the World Trade Organisation, (Hart Publishing 2007); S. Joseph, D. Kinley, \& J. Waincymer, The World Trade Organization and Human Rights: Interdisciplinary Perspectives, (S. Joseph, D. Kinley, \& J. Waincymer, eds., Edward Elgar 2009).
} 
After all, even the recent economic and financial crisis, which has so dramatically attacked the very model of Western capitalism, has to some degree strengthened the pretenses of State structures. These structures have played a decisive role in searching out solutions to the problems of global economics, by exercising forms of inter-State sovereignty, and not by their abolishment.

Instead, what is destined to change is a certain quality of (national) exclusiveness attributed to the subject of our research. If we failed to acknowledge the change, we could reach only a very limited understanding of a reality which is no longer polarized around the sovereign State.

\section{ECONOMY, RIGHTS AND INSTITUTIONS: A COMPARATIVE APPROACH}

In the attempt to reconsider the instruments of comparison, we discern a paradox: comparative law is often used to favor a process of homologation or unification of law. In fact, while comparison necessarily presupposes a difference between law systems, we might be led to imagine a selfdestructive process in comparison, since it offers its own instruments and results on the altar of global homologation.

No wonder that comparativists so often ask themselves about the alternative between rules' competition and their homologation.

In any case, legal problems are much more complex than any simple homologation of the rules (which is possible and not imminent). For some time now, in fact, observers have understood that, the distinctions and divergences between systems usually hinge on the interpretation and applications of the rules themselves, the vocabulary used by jurists, the categories by which rules can be understood, and finally, the mentality intrinsically linked to the social environment involved.

However, the new set of conditions brought about through the globalization process raises questions about the impact which the progressive weakening of national borders has on comparison projects, on notions consolidated within single systems of traditional juridical concepts, on the disruptions experienced by certain legal categories in interpreting reality. New frontiers emerge to divide the world, and they no longer divide it on the basis of territory or geography.

In any legal sector we might consider, whether it pertains to the property of financial markets, human rights, Internet regulation, family law, environmental law, or labor law, we can detect not only persistent diversities between the rules of national systems, but also proposals and perspectives favoring homologation, deriving from supra-national 
organisms or from private processes of self-regulation. In this complex framework, we clearly detect space reserved for comparison, understood not as a mere listing or juxtaposition of specific rules, but as a search for the intimate reasons which have led to their formation and, above all, to their possible circulation. We must discover the formative elements favoring or opposing the rules' reception and possible adaptation.

Our analysis must not neglect a fundamental alternative in the conception of the global juridical order being planned: an alternative involving the dualism between market and institutions. Some processes lead to a de-territorialization of the economy, to markets' demand for selfregulation, to the autonomous expanse of globalization structures; others lead to a re-appropriation of State normative space, to the strengthening of administrative law, and to the outbreak of new conflicts not based on territory. Such processes may either foster the homologation of law or exalt juridical differences. Comparative law studies must read, if not draw up, the road map.

The problem of juridically constructing the global system, indeed, hangs in the balance between two opposing factors. On one side, we see the hypothesis of global governance as an expression of the market's selfregulatory capacities; in this case, it would be conceived as a spontaneous trans-national product appearing in the form of a new lex mercatoria. On the other side, we see a vision in which specific international political actors are assigned great importance; they would supposedly operate according to a neo-colonization scheme which has shucked off the forms of national States.

The concept lex mercatoria itself may lead to confusion, if its modern evolution is depicted as a simple outcome of its medieval forms. On one hand, global law presents itself as the final product of private autonomy and the arbitrational jurisdiction expressing it. On the other hand, simultaneously, it is a law imposed by international organizations operating according to the traditional schemas of sovereignty, even in a non-territorial context; it is imposed ratione auctoritatis over national laws. For instance, the WTO imposes through the persuasion proper to economic power, certain restrictions on the action of national governments, in numerous legal sectors, from commerce to intellectual property, from the environment to the politics of labor. This "orienting" capacity produces clear results in all the juridical dimensions of national legal systems, conditioning them heavily. This consideration by itself sheds light on the new horizons which comparative studies must confront, in order to produce a more structured understanding 
of reality. $^{16}$

At the same time, the WTO itself is clearly an expression of the predominant economic-juridical culture; it models a social organization mirroring a specific tradition, and aspiring toward the world-wide exportation of normative, interpretative categories.

The story often told in accounts of the Western legal tradition confirms a tendency to export a generic reference to the rule of law, within the public sphere, and to a set of rules reflecting the principles of a competitive free market, in the private sphere; such messages bear enticing labels which are seemingly non-political. $^{17}$

In this case as well, the instruments of comparison can help us decipher the impact made by the new "homogenous" disciplines on the local juridical network. In the area of legal transplants itself, comparative scholarship has sharpened its capacity to explain the dynamics which involve single rules or entire institutions, in its frequent attempts to reveal the relationships between them and planned levels of economic efficiency. ${ }^{18}$

As they continue their inquiry into market discipline, these actors on the international scene may also propose models for the disciplining of rights: models enrobing universalism with the traits of humanism, and suggesting the imposition of a common set of instruments defining protection techniques. In this case, comparative thought becomes ever more necessary, clarifying a condition of possible conflict between the new legal instruments and the juridical traditions they must deal with: a condition causing possible rejection, or the erecting of new barriers against the instruments' entry.

In this particular perspective as well, comparative law studies will necessarily find enrichment through the object of their inquiry. It will make clear that alongside national legal systems, today's juridical regulation, both domestically and globally, takes into account a series of declarations which

\footnotetext{
${ }^{16}$ As clarified by G. Ajani, Navigatori e Giuristi. A Proposito del Trapianto di Nozioni Vaghe, 7 Io Comparo, tu Compari, Egli Compara: Che Cosa, Come, Perché? (V. Bertorello, ed., Giuffrè 2003), our examination of the norm's building process is affected today by the presence of a third factor, the sponsor of circulation, such as the International Monetary Fund or the World Bank; the sponsor may be devoid of its own formal juridical model, but it clearly grasps the function of the economic model which one intends to endow with juridical forms.

${ }^{17}$ See U. Mattei, \& A. Di Robilant, International Style e Postmoderno Nell'architettura Giuridica Della Nuova Europa. Prime Note Critiche, 89 Riv. Crit. Dir. Priv. (2001); A. Di Robilant, Non Soltanto Parole. In Margine ad Alcuni Itinerari di "Law and Art", 3 MATERIALI PER UNA STORIA DELla CULTURA GIURIDICA 483 (It. 2001).

${ }^{18}$ On this point, see M. Graziadei, Comparative Law as the Study of Transplants and Receptions, THE OXFORD HANDBOOK OF COMPARATIVE LAW 459 (M. Reimann, \& R. Zimmermann, eds., Oxford University Press 2006).
} 
are formally non-binding, guidelines drawn up by non-governmental organisms, and models of market discipline created by professional communities. Together, such elements are known as "soft law". They are an important factor in modern de-juridification. Once again, this context relates to the crisis of traditional borders: indeed, the importance of soft-law schemas in the formation of laws is undeniably linked to the permeability of legal systems to non-territorial input, given not only the global complexity of today's problems, but also the multiplicity of power centers involved in their solution.

\section{DisARTICULATION AND INTEGRATION OF ENTERPRISE STRUCTURES. THE CASE OF CO-EMPLOYMENT}

In the area of Labor Law, the plurality of external sources contributing to the legal system has long been a well-known phenomenon. The Labor jurist is accustomed to dealing with a multi-level system of rules, some "hard" and some "soft" (State norms, Supra-national sources, Collective Agreements, Internal Company Regulations). The economic crisis and the globalization of markets has, of course, created a phenomenon of progressive disarticulation in enterprise structure ${ }^{19}$, followed, most recently, by a tendency of Companies (even when fragmented and de-structured) to reassemble in a contract system of entrepreneurial integration.

The phenomenon of disarticulation among Enterprise Structures has led many governance sectors of the European Union to search out new logical frameworks in order to meet the need to unite several parties in a shared role as "Employer". The purpose here-a markedly remedial one-is to extend, duplicate or, at any rate, redefine their debt status. ${ }^{20}$

From the perspective of juridical regulation, the problem lies in the fact that, "traditional" Labor Law had been born and had developed with an exclusive focus on the figure of the Labor Provider, while considering the labor relation a substantially biunivocal. ${ }^{21}$ Specifically, the Labor Law system tended to limit the insertion of third parties into the relation between

\footnotetext{
${ }^{19}$ In the text, we address the problem of what David Weil calls the "fissurization" of work. See D. Weil, The Fissured Workplace: Why Work Became So Bad for So Many and What Can be Done to Improve It, (Harward University Press 2014).

${ }^{20}$ On this subject, see Prassl, The Notion of the Employer, THe LAw QuARTERLy ReVIEW 380-398 (2013).

${ }^{21}$ See recent contributions to the discussion: L. Corazza, \& O. Razzolini, Who is an Employer?, W.P. C.S.D.L.E. "MASsimo D'ANTONA".INT 110 (2014). Available at http://csdle.lex.unict.it/workingpapers.aspx; S. Deakin, The Complexities of the Employing Enterprise, Boundaries AND Frontiers of LABOUR LAW 275 (G. Davidov, \& B. Lagille, eds., Oxford and Portland Oregon: Hart Publishing 2006).
} 
worker and employer. For quite some time, for example, the Italian juridical system has forbidden interposition between the two parties, coherently with the idea that, the utilization of labor services implies the assumption of responsibilities proper to the employer's role.

At a certain point, traditional Labor Law has had to deal with the above-mentioned phenomenon of fragmentation, in the productive cycle, according to a model driven by new networking schemas based on the aggregation and interactions between juridically distinct parties interconnected by bonds of ownership or contract. ${ }^{22}$

Questions concerning the role of the employer and his/her "flexibilization" have led to the need for juridical systems to regulate, first, the externalization stage for activities, and then, the moment of reappropriation or collaboration between companies in carrying out given phases of production.

New rules then arose for utilizing the work of others, for subcontracting and outsourcing, for regulating worker relocation and the use of employment agencies. Progressively and innovatively, we have seen a duplication of employer prerogatives assigned to distinct parties.

Lately the phenomenon of company networks has stimulated further reconsideration concerning the employer and the limits of his/her role. There is a growing tendency to accept the concept of "co-employment", which first emerged in connection with labor relations pertaining to groups of Companies.

A comparative analysis of the present state of labor norms shows that, as regards the problem of labor discipline within Company networks, juridical systems have worked in a fragmentary, disorganized way. Nearly always, they have accorded workers tutelage ex post, based on the principle of responsible solidarity. ${ }^{23}$

In particular, legal systems seem to have focused on the pathological aspects of productive decentralization and of group conditions, seen as phenomena capable of eluding norms set up to protect workers.

In acknowledging the importance of such groups, a series of indicators have been established for ascertaining the dimensional requisites necessary for offering worker guarantees, and for verifying the correct exercising of re-hiring processes in cases of dismissal for objective reasons. The possibility of hiring the worker in a different company belonging to the

\footnotetext{
${ }^{22}$ Cfr. W. Powel, Neither Market nor Hierarchy: Network Forms of Organization, RESEARCH IN Organizational Behavior (L. L. Cummings, \& B. Staw, eds., San Francisco: Jai Press 1990).

${ }^{23}$ On this discussion, see the international reports presented at the 2006 XVIII World Congress on Safety and Health at Work. Available at http://www.issa.int.
} 
group is assessed, even in cases where the new workplace lies in a foreign Country. Inquiry is made into the responsible solidarity among Companies in the Group, meant to guarantee the payment of workers formally employed only by a single Company.

This interpretative pathway, clearly and expressly traceable in Italian jurisprudence, finds ample analogies in French, Spanish and British systems.

French jurisprudence, indeed, has played on the substantial confusion of interests between several companies in order to refer the cause réelle et sérieuse of economic dismissal not only to the formal employer, but to the entire group of Companies. ${ }^{24}$ This means that, when several entities within a group has the status of employer, the termination of one of them is an economic cause of dismissal only if justified by economic difficulties, by technological changes, or by the need to safeguard competitiveness within the entire industrial group to which they belong. ${ }^{25}$

Dealing with a differing schema of unité économique et sociale, French jurists have striven to define the perimeter proper to the formation of a comité d'entreprise and to the appointment of délégués syndicaux. Art. L. 1235-10, Code du travail, in a version previous to the application of law 14 June 2013, n. 2013-504 on sécurisation de l'emploi, in the event of collective dismissals sanctioned the validity of the plan de sauvegarde de l'emploi through means available not only to the single company, but to the unité économique et sociale, i.e., the group. Despite referral to the figure of the co-employer, in the French system, legal decisions continue to consider the labor contract in a bilateral sense; therefore it remains debatable whether the co-employeur is liable in light of an indirect establishment of a labor relation: that is, in an extra-contractual capacity.

The line of reasoning followed by Spanish jurisprudence is analogous, though more restrictive. Typically, co-employment in Spain has gained acceptance as an instrument to prevent fraud. It is considered useful in calculating the indemnity imposed for illegitimate dismissal of a worker, according to seniority. Similarly, in the area of collective labor relations, cotitularidad fáctica of the labor relation may allow for the recognition of delegados de personal and a comité intercentros (Art. 87, Estatuto de los Trabajadores) corresponding to the entire company group. The phenomenon of cotitularidad in the labor relation may arise by way of

\footnotetext{
${ }^{24} \mathrm{~F}$. Gea, Le Droit du Licenciement Economique à L'épreuve de la Sécurisation de L'emploi, DroiT Social 210 (Fr. 2013); Id., Groupe de Société et Responsabilité, RDT 230 (Fr. 2010); B. Teyssié, Les groupes de Sociétés et le Droit du Travail, DS 735 (Fr. 2010). See also J. E. Ray, \& J. Rojot, The Fissured Workplace in France, COMP. LAB. LAW \& POL. JOURNAL 163-180 (2015).

${ }^{25}$ Cass. Soc., January 18, 2011, n. 09-69.199, Junheinrich, Bull. Civ. 22 (2011).
} 
contract (when the contract itself stipulates a plurality of employing parties), in agreements reached between group companies. Such agreements strive to constitute a unified organización laboral endowed with a plantilla única.

In Spain, however, sometimes in the absence of explicit agreements, the group may operate as a single organization, if the workers' activity is meant to satisfy the interests of several companies in the group. In this case, the employment gains the responsible solidarity among co-employers concerning all the employer obligations stipulated in the labor contract. ${ }^{26}$

According to Spanish Law, a unified center of attribution for the labor relation exists when there is a confused usage of work activities. Confused usage emerges when simultaneously, or in different periods, several different employers exercise management powers, or the assets of different companies are combined. It may also emerge in the unification of management, when different companies work together in reaching their main decisions. Finally, it may emerge in a group's self-presentation as unidad empresorial, i.e., a confused portrayal of apparent entrepreneurial unity, meant to deceive a third party in good faith.

In order to demonstrate the existence of a unified center of responsibility for labor relations, the living law has accepted several indicators which recur in similar ways in France and Spain. In those countries, the group is considered as a site of "confusion" for single spheres of interest. In France, the plurality of employers (employeurs conjoints) reflects a "substantial confusion of interests, activities and management" (so-called Triple confusion). ${ }^{27}$

According to the Cour de Cassation, this result, on the corporative level, from a "consistent" capital share dominance by one company over the other; and concretely, when we find a constant influence exercised over strategic decisions taken by the subsidiary company: for example, when the controlling company decides to close a factory. Here, apparently, the promiscuous and non-differentiated use of the labor activity is not emphasized, contrary to decisions in the Italian system concerning the criteria of responsibility in labor relations.

In the United Kingdom, the concept of "associated employers" is linked to the direct or indirect control of another company or other companies, by absolute shareholder majority (Section 231, Employment Rights Act 1996, formerly Section 30, Trade Unions and Labour Relations

\footnotetext{
${ }^{26}$ Cfr. J. Baz Rodriguez, Las Relaciones de Trabajo en la Impresa de Grupo, (Granada 2002), passim (Sp).

${ }^{27}$ Cfr. E. Peskine, L'imputation en Droit du Travail, Revenue du Droit du Travail 347 (2012); Vari, Groupes de Sociétés et Droit du Travail, DS 7/8 (2010).
} 
1974).

In such situations, the law stipulates that, in a case of "unfair dismissal", the judge may order the so-called "re-engagement" of the worker, even by an "Associated Employer" (Section 115 ERA 1996). Moreover, when the worker passes from one company to another, his/her seniority must be preserved; the entrepreneurial unification must also apply to the recognition of certain rights, once a certain dimensional limit has been reached. $^{28}$

The limiting of normal employer responsibilities only to persons formally involved in the negotiated relationship was tied to the vertically integrated industrial model. For some time now, this model has no longer corresponded to the real socio-economic scenario.

Today, in fact, two companies may be considered "associated" if one exercises direct or indirect control over the other, or if both are subject to the direct or indirect control of a third company.

The distinction lies, then, in the existence of "control", an expression that leaves wide room for interpretation, above and beyond the factor of majority shareholder ownership.

\section{The Italian CASE: ENTERPRise Network LABOR SituATED BETWEeN DE-REGULATION AND NEO-REGULATION}

Decree Law n. 76 of 2013 (converted into Law n. 99 of 2013) introduced into the Italian system a norm difficult to interpret: the third subsection of the Article 30, Legislative Decree n. 276, 2003. ${ }^{29}$ It embodies an absolutely new element in the world of Comparative Law.

Until 2013, like other systems, the Italian one moved along two diverging pathways. On one hand, it aimed to impose models of solidarity/responsibility on industrial processes and subcontracting agreements; on the other, to repress instances of interposition when rules

\footnotetext{
${ }^{28}$ On the British model, cfr. W. Njoya, Corporate Governance and the Employment Relationship: The Fissured Workplace in Canada and the United Kingdom, Comp. LAB. LAW \& POL. Journal, 163121-142 (2015); S. Deakin, The Changing Concept of the Employer in Labour Law, 30 InDUSTRIAL LAW Journal 72-84 (2001); H. Collins, Ascription of Legal Responsibility to Groups in Complex Pattern of Economic Integration, 53(6) THE MODERn LAw REVIEW 731-744 (1990).

${ }^{29}$ The new norm reads: "When the relocation of personnel occurs between companies which have signed a company network contract having validity according to legal decree February 10, 2009, n. 5, modified and converted into law April 9, 2009, n. 33, the interest ascribed to the dislocating party arises automatically given the network's operating force, except in the presence of worker mobility norms foreseen in Civil Code Art. 2103. Moreover, the enterprises themselves may avail themselves of co-employment regimes for personnel engaged through rules established by the network contract itself" (trans. by the Author).
} 
were violated which, within strict limits, allowed for a distinction between the employer signatory of the labor contract and the party receiving the labor service (administration of labor, subcontracting and relocation).

The norm introduced in 2013 subverts preceding rules by expressly permitting the sharing of employed personnel, according to limits established by the (typical) network contract, not only in the case of relocation, but also in the context of contractual relations between Companies.

The potentially revolutionary aspect here lies in the normative provision foreseeing, for Companies stipulating a "network contract" (which is a contract of commercial nature), the possibility of co-employing personnel hired according to rules stipulated by the network contract itself.

The novelty consists in the recognition of labor-law effects on the conjoining of enterprises which is based on contract obligations governed by the rules of contract law. Such effects are asymmetrical, and difficult to foresee. They tend to endow private parties with wide autonomy.

The new norm makes it very difficult to determine the limits that must apply to a network contract, as regards both the definition and the real regulation of "co-employment". The letter of the Law seems to set no limit on the signatories of the (commercial) network contract, concerning the definition of co-employment norms: Neither in terms of real responsibility nor in defining the concept of "co-employment" itself.

Clearly, a big problem arises from the hazy nature of the very term "coemployment" (codatorialità or its equivalent, in translation to other languages). The difficulty lies in determining whether this new legal concept adopted by the Italian legislator must be understood as a mere semantic variant of contitolarità (co-ownership or shared roles) in labor relations. Does it simply imply attributing a single role to a plurality of subjects or is it, on the contrary, an autonomous juridical concept capable of granting the parties signing a network contract the option of splitting up the active and passive positions resulting from the labor contract, in their pursuit of networking goals (as specified by the legislator)?

Taken in this wider sense, "co-employment/codatorialită", as triggered through a networking contract, appears as an instrument capable of fostering dissociation among various juridical stances arising from Labor relations.

In this capacity, it allows for the coexistence of several holders of the powers attributed to the Employer. Those powers may be exercised according to rules autonomously established by themselves in the pursuit of strategic goals defined in the networking plan.

Independently of any attempt to reach a correct interpretation of the 
new law, subsection 4-ter, Art. 30, Legislative Decree n. 276 of 2003, we cannot help but stress that the norm builds a bridge between Labor Law and Commercial Law. We do not know what the final result will be for the current legislative trend. In any case, its potential appears to be potentially explosive, especially in the long run.

The new phenomenon of "typical co-employment" fully enters into the flexibility process affecting Labor Law. In the case we have examined, this process is driven by a direct transfer of functions to the private autonomy of parties signing the networking contract, which is a typical enterprise contract.

Research concerning the figure of the employer in joint ventures, which deeply challenged scholars before the year 2013, has directed attention to deconstructivist thought. ${ }^{30}$ That attraction arose while observing the phenomenon of deconstruction clearly manifest in the transformation of enterprises and of their emblem, i.e., the pair, employer/employee. Struck by changes occurring in systems of production and labor organization, observers set out to (re-)construct a notion of "co-employment" understood as a theory on liability-sharing in labor relations.

Such theoretical reflection was followed by the legislative intervention of 2013, which somehow responded to the semantic conundrum by juridifying the term "co-employment/codatorialità" without, however, providing any normative juridical description or explication.

This "blank-check" normative technique follows the legislative trend of favoring "soft" models of regulation, choosing to "regulate" social phenomena without imposing detailed regulations on them. In Italian, regolamentare implies dictating rules from outside; while regolare, instead, means to observe the rules necessary for the stable functioning of an organization. $^{31}$

Formulation of the new Law (the quoted subsection n. 4-ter, Art. 30, Legislative Decree n. 276 of 2003) emblematically expresses the legislative will to redistribute roles between the legislator and private negotiation, according to a programmatic logic of government politics adapted to the

\footnotetext{
${ }^{30}$ See V. Speziale, Il Datore di Lavoro Nell'impresa Integrata, LA FigURA DEL DATORE Di LAVORO. Articolazioni e Trasformazioni. Atti del Convegno Nazionale A.I.D.La.S.S., CATANia, 21-23 MAGGIO 200977 (Milano 2000), expressly referring to essays by J. Derrida, 1967 (J. DERRIDA, De LA Gramatologie (Paris: Seuil 1967)). For a critical reading of Derrida's views, see N. A. SAlingaros, Anti-ARChitecture And DeConstruction (2nd ed., Solingen: Umbau-Verlag 2008).

${ }^{31}$ See A. Supiot, Homo Juridicus. Essai sur la Function Anthropologique du Droit, (Paris: Seuil 2005). Supiot then points out that, "according to cybernetic theory, only adequate regulation, not rigid regulamentation, can protect society from entropic disorder: that is, from nature's tendency to deteriorate what is ordered and destroy what is comprehensible" (trans. by the Author).
} 
dynamics of relations between private parties.

In this perspective, the conventional legal contract becomes an instrument for jurists, who program its negotiation within the limits set out by objectives defined by the law itself. In other words, the Italian norm of 2013, by introducing the function of establishing rules for the hiring of employees into the indefinite regulatory dynamics of the networking contract, may threaten to destabilize the system. In fact, in the legislator's intention (at least the apparent intention), the networking contract takes on a role as a source of law; the negotiation agreement becomes instrumental in programming the internal organization of work activities in harmony with networking goals.

Given the structural characteristics of the norm, some observers have stressed that, this case of Italian reform suggests a hypothesis surpassing mere "de-juridification", understood as a "formal" sort of technique for seeking answers amid the rationale of the autonomous economic-social subsystem. They point out, in fact, that, the State refrains from dictating its rules here, not in order to prevent an excessive normative pressure from provoking colonization of the sub-system being regulated, but out of the opposite need: To compensate for the supposed incapacity of the State to influence a reality which has become too complex to govern from above, by way of a single center of power. ${ }^{32}$

\section{THE ENTERPRISE NeTWORK CONTRACT. RELATIVE NORMS AND IMPORTANT GUIDELINES PERTINENT TO LABOR LAW}

In the framework of the new Italian norms, the disciplining of relocation and co-employment of personnel employed in company networks is in part subject to the rules established by the parties signing the network contract.

The only restriction seeming to emerge with respect to the autonomy in negotiations enjoyed by parties signing the commercial contract at hand, is found in the first part of the norm, where the legislator stresses that in order to function as a pre-supposition for recognizing an implicit interest in relocation, the network contract stipulated between "co-employment" enterprises/parties must be valid.

\footnotetext{
${ }^{32}$ Cf. S. P. Emiliani, La Sfocatura della Disciplina della Codatorialità: un'ipotesi di ricerca, Dall'ImPResa a Rete ALle Reti D'IMPReSa 185-202 (M. T. Carinci, eds., Milano: Giuffrè 2015). See also M. Biasi, Dal Divieto di Interposizione Alla Codatorialità: Le Trasformazioni Dell'impresa e le Risposte Dell'ordinamento, Contratto di Rete e Diritto Del Lavoro 117-161 (G. Zilio Grandi, \& M. Biasi, eds., Torino: Wolters Kluwer Italia 2014). E. Menegatti, Mending the Fissured Workplace: The Solution Provided by Italian Law, Comp. LAB. LAw \& POL. Journal 91-120 (2015).
} 
On one hand, this emphasis serves to restrict the rule's operative capacity to the juridical figure of the company network, as defined by the legislator (and this constitutes the legal precept). On the other hand, by evoking the validity of the contract itself, and thus highlighting a requisite which is abundantly obvious, the emphasis may indicate the legislator's intention to restrict the parties' autonomy by fixing the rules of "coemployment" within the context of Commercial Law.

Let us stop to reflect on the "company network" as defined in the Italian norm of 2013. We might note, first of all, that, with respect to the term "company network" as used in research studies concerning the figure of employer in a web of companies, the network contract as it appears in the 2009 Law is presented as a particular, special, circumscribed case. In this restricted sense, then, the term "company network" has a specific technical, juridical meaning. Therefore, the corresponding case of co-employment also finds itself operating in a restricted area, correlating to that of the commercial case at hand.

In the network contract as regulated by Italian Commercial Law, the Parties' autonomy is strictly limited in the functional sense, but is not subject to any limits as regards the content of obligations and rights which are reciprocally assumable.

The numerous changes made during the last five years in the (Commercial-Law) regulation of the network contract reveal a process of progressive expansion in the scope of contracts, which currently allow a plurality of entrepreneurs accepting a shared program to construct various kinds webs between one another, and to promise to "collaborate in predetermined forms and areas pertaining to the exercising of their enterprises, or to exchange information or services of an industrial, commercial, technical or technological nature", with the aim to pursue "the goal of increasing, individually and collectively, their innovative capacity and their competitiveness on the market".

More specifically, in order to validate and perfect the instrument, it is essential to indicate "strategic goals of innovation and growth in the competitive capacity of participants, and agreed ways ... in which to measure progress toward these goals". This provision relates to the cause justifying a network contract: according to the expressio causae mechanism, the parties must first state the cause, express it concretely, and then act upon it. If strategic goals are not indicated, the contract is null due to the original defect in its inception.

On the other hand, the Law leaves great freedom to regulate the object of the contract itself. The networking program is the proper site for 
enucleating "the rights and obligations assumed by each participant", but as regards the content of these reciprocal rights and obligations, the parties' autonomy is almost unlimited, as long as those rights and obligations are functional to reaching the goal legally connoting the contract.

In the initial part of the norm, indeed, the legislator indicates the area of possible obligations assumable by the network participants, using the following provision: "with the network contract, several entrepreneurs pursue the goal ... and to this end, they commit themselves, based on their shared program ...". The contents of these obligations may vary, to the point of encompassing any entrepreneurial service.

More generally, in the background to the new regulation introduced by the Italian legislator, the problem remains of sharing responsibilities in the problematic area of co-employment created by the network contract.

In Circular letter n. 35 of 2013, The Italian Ministry of Labor stated that, "in the area of possible criminal, civil or administrative responsibilities - and therefore in the area of punishability for possible illicit acts - we shall thus need to refer to the contents of the network contract, without 'automatically' presupposing solidarity among all participants in the contract". Substantially, the Ministry thus the reference implied by the new norm, to "rules established by way of the network contract itself", even in the effort to govern responsibility.

The solution proposed by the Ministry has been sharply criticized in many areas of Italian legal doctrine. Many observers believe that, the system of co-employment is an expression of a "technique of responsible solidarity between two or more enterprises when the management and controlling power is exercised conjointly and, more generally, as a technique fostering 'recomposition' of the entrepreneurial figure". They thus conclude that, the effect of joint responsibility cannot be waivered. ${ }^{33}$

Without stopping to discuss the specific interpretative question inherent in the Italian system of labor law, it seems clear that, the coemployment norm lies at the very heart of the system of safeguards traditionally built up for the protection of the weak contracting party. That heart is the unwaiverability of safeguards, effectively defined as the "foundation and central problem of labor law". 34

\footnotetext{
${ }^{33}$ In this direction, A. Perulli, Contratto di Rete, Distacco, Codatorialità, Assunzioni in Agricoltura, IV Il Nuovo Diritto del Lavoro, La Riforma del Mercato del Lavoro 463-504 (L. Fiorillo, \& A. Perulli, eds.,Torino: Giappichelli 2014).

${ }^{34}$ See C. Cester, La Norma Inderogabile: Fondamento e Problema del Diritto del Lavoro, Relazione, XIII Congresso Nazionale "Inderogabilità Delle Norme e Disponibilità dei Diritti", organized by Associazione Italiana di Diritto del Lavoro e della Sicurezza Sociale (A.I.D.LA.S.S.), held April 1819, 2008 at Modena, Available at http://www.aidlass.org (It.).
} 
For the reasons mentioned above, the lexical structure of the 2013 norm thus reflects a dramatic, revolutionary force with respect to the traditional regulatory model. In particular, the norm destroys the linearity of traditional Labor-Law discourse. Indeed, it imperatively activates a dialogue between the rationale of labor-law discourse and that of commercial law, without resolving the serious problem facing us at the end of the line: the capacity for parties signing the commercial contract, to employ forms of protection set up to favor workers. The opening of this dialogue will shed light on the problem referred to above as "substantial justice". The problem is extremely important, in the face of common economic processes and in relation to global tendencies in which States retreat from their former roles in disciplining relations between private parties.

\section{CONCLUSIONS}

It is clear that, the process of de-juridification represents one of the main trend that can be detected in the evolution of law nowadays. In this perspective, even comparative law is in need of an overhaul if it is to take its rightful place as an important legal science, taking into account different features of this process.

Recent reforms in many European countries show a trend towards a relaxation of rules, inspired by the aim to stimulate growth in employment. In this context, in the field of labor law, one of the main example of the process of de-juridification is the newly-introduced concept of "joint employment". The process of de-juridification clearly invests labor law, in particular within enterprise networks, where arrangements under joint employment seem to give the parties of a commercial contract the highest standard of contractual freedom. This social phenomenon is not therefore regulated by detailed legislative provisions, but simply through non-specific norms inspired by general goals.

In considering several recent reforms of labor law in European countries, it has been possible to determine the real level of de-juridification currently present within western legal tradition. 